\title{
STEFAN WYSZYŃSKI I JÓZEF TISCHNER - UKRYTY DIALOG O NAJWAŻNIEJSZYCH POLSKICH SPRAWACH
}

DOI: http://dx.doi.org/10.12775/SPLP.2021.019

\section{Streszczenie}

Stefan Wyszyński i Józef Tischner to dwaj wybitni przedstawiciele polskiej myśli katolickiej dwudziestego wieku. Działali na różnych polach. Wyszyński jako Prymas Polski niósł ciężar odpowiedzialności za losy całego polskiego Kościoła w wyjątkowo trudnych dla niego czasach programowej ateizacji i dominacji antykościelnej propagandy, dlatego rozwijał w sobie cnoty męża stanu i myślał w kategoriach ogólnonarodowej strategii ewangelizacyjnej. Tischner działał przede wszystkim w dwóch obszarach: jako filozof i jako duszpasterz, a jego kompetencje i zainteresowania dotyczyły filozofii, która „rodzi się z bólu”, chce ten ból wyrażać i próbuje mu zaradzać. Swój głęboki i oryginalny zmysł filozoficzny wykorzystywał w codziennej pracy duszpasterskiej, co przynosiło imponujące efekty. Pomimo owej różnicy zakresu i stylu działania, obaj wywarli ogromny wpływ na duchowy i intelektualny kształt polskiego katolicyzmu. Choć nigdy nie spotkali się osobiście i nie mieli okazji współpracować ze sobą, można stwierdzić, że ich praca wychowawcza i intelektualna wytworzyła swego rodzaju „ukryty dialog” w polskiej przestrzeni publicznej. Najważniejsze płaszczyzny i owoce owego dialogu przedstawia niniejszy artykuł.

Słowa kluczowe: Stefan Wyszyński, Józef Tischner, dialog, patriotyzm, wierność, etyka chrześcijańska 


\author{
STEFAN WYSZYŃSKI AND JÓZEF TISCHNER - \\ A HIDDEN DIALOGUE \\ ABOUT THE MOST IMPORTANT POLISH MATTERS
}

\begin{abstract}
Stefan Wyszyński and Józef Tischner are two outstanding representatives of the Polish Catholic thought in the twentieth century. They were active in various fields. As the Primate of Poland, Wyszyński carried the burden of responsibility for the fate of the entire Polish Church in exceptionally difficult times of programmatic process of atheization and domination of anti-church propaganda, which is why he developed the virtues of a statesman and thought in terms of a national evangelization strategy. Tischner worked primarily in two areas: as a philosopher and as a priest, and his expertise and interests were related to philosophy, which is „born of pain”, wants to express that pain and tries to remedy it. He applied his deep and original philosophical sense to his daily pastoral work, with impressive results. Despite this difference in scope and style, they both exerted an enormous influence on the spiritual and intellectual shape of Polish Catholicism. Although they never met in person or had the opportunity to work together, it can be said that their educational and intellectual work created a kind of ,hidden dialogue” in the Polish public space. The most important aspects and fruits of that dialogue are presented in this article.
\end{abstract}

Keywords: Stefan Wyszyński, Józef Tischner, dialogue, patriotism, faithfulness, Christian ethics

Stefan Wyszyński (1901-1981) i Józef Tischner (1931-2000): dwie wybitne postacie i dwie odmienne osobowości polskiego Kościoła powojennego i współczesnej polskiej myśli katolickiej, których życie wypełnia łącznie całą przestrzeń XX stulecia. Dzieliła ich duża różnica wieku - ponad 30 lat - lecz żyli i działali twórczo w tej samej, powojennej epoce, naznaczonej (jak zwykle w polskich dziejach) potężnym ładunkiem dramatyzmu.

Należeli do dwóch sąsiednich pokoleń. Aktywność duszpasterska i publicystyczna Wyszyńskiego rozpoczęła się jeszcze przed wojną ${ }^{1}$, lecz najważniejszy

Według ustaleń Anny Rastawickiej, ,,po święceniach [w 1924 r.] ksiądz Wyszyński został wikariuszem w katedrze włocławskiej. Jednocześnie był redaktorem diecezjalnego „Słowa Kujawskiego”. [Od 1930 r.] wykładał w seminarium, był redaktorem [...] „Kroniki Diecezji Włocławskiej”, a następnie „Ateneum Kapłańskiego”. Prowadził też bardzo intensywną pracę społeczną. Działał w Chrześcijańskich Związkach Zawodowych, wykładał na Chrześcijańskim Uniwersy- 
okres jego działalności publicznej to czas sprawowania przezeń funkcji prymasa Polski (lata 1948-1981). Kiedy na konsystorzu w Stolicy Piotrowej papież Pius XII powołał Wyszyńskiego do godności arcybiskupa gnieźnieńskiego i warszawskiego oraz prymasa, Tischner był w klasie maturalnej LO w Nowym Targu. Jako prezbiter rozpoczął swoją posługę w roku $1955 \mathrm{w}$ Jawiszowicach pod Oświęcimiem, jako autor debiutował w tymże roku krótką recenzją książki lowańskiego filozofa i teologa Fernanda Van Steenberghena Epistemologia ${ }^{2}$, lecz pierwsze samodzielne przemyślenia zawarł w artykule Czy egzystencjalizm jest humanizmem?, ogłoszonym w 1958 roku w warszawskim kwartalniku Homo Dei (była to polemika z ateistyczną filozofią J.-P. Sartre'a). Od 1964 roku publikował już regularnie, a jego poglądy (głoszone również ustnie podczas kazań, rekolekcji i konferencji) stawały się coraz szerzej znane i komentowane. Można więc powiedzieć, że przez blisko ćwierć wieku (od pierwszych wypowiedzi Tischnera do śmierci Prymasa) w polskiej przestrzeni publicznej rozbrzmiewał ich ważny i inspirujący, choć niekonicznie zharmonizowany dwugłos. Według jednej z koncepcji filozofii spotkania można go określić jako ,ukryty dialog”3.

\section{RÓŻNE DROGI, JEDEN CEL}

Wyszyński i Tischner należeli nie tylko do różnych pokoleń, ale także do dwóch zdecydowanie różnych szkół myślenia i formacji duchowej. Reprezentowali odmienne typy osobowości i temperamentu. Stawiali przed sobą podobne cele, lecz dążyli do nich rozbieżnymi drogami. Dlatego zapewne, choć szanowali się nawzajem i cenili, nie nawiązała się między nimi nić sympatii i nie doszło do prób zbliżenia stanowisk ${ }^{4}$. Żyli jednak w tym samym kraju, w tych samych trudnych

tecie Robotniczym, organizował spotkania, pisał broszury o tematyce społecznej”. A. Rastawicka, Ten zwycięża, kto miłuje. Życie i nauczanie prymasa Stefana Wyszyńskiego, Warszawa 2019, s. $27-28$.

2 Zob. http://www.tischner.org.pl/bibliografie-tischnera (1.10.2021).

3 Por. A. Fiut, Ukryty dialog, ,Teksty Drugie” 2000, 3, s. 148-156.

4 Prymas Wyszyński nie miał szczególnego powodu do zainteresowania się osobą ks. Tischnera, przynajmniej do czasu, gdy ten stał się postacią szeroko znaną w kręgach międzynarodowych dzięki swej przyjaźni z Karolem Wojtyłą, tj. pod koniec lat siedemdziesiątych. Wtedy jednak wydarzenia toczyły się tak szybko i intensywnie, że trudno się dziwić, iż nie doszło do ich spotkania. Józef Tischner ze swej strony był raczej zdystansowany wobec poglądów i poczynań zwierzchnika Kościoła w Polsce. Świadczy o tym m. in. następująca wypowiedź, dotycząca lat sześćdziesiątych: „Wyszyński reprezentował kierunek zainteresowań [...] historyczno-polityczny [podczas gdy ja] miałem wtedy problemy dwojakiego typu. Jeden to był problem Ingardena w jego sporze z Husserlem o idealizm. Drugi to był problem mojego penitenta, słuchacza albo ucznia”. A. Michnik, J. Tischner, J. Żakowski, Między panem a plebanem, Kraków 1985, s. $137-138$. 
czasach, wymagających równocześnie rozwagi i odwagi. Żadnemu z nich nie brakowało jednej ani drugiej.

Mimo różnego przygotowania intelektualnego oraz nieco odmiennego wzorca duchowości wiele ich łączyło. Przede wszystkim głęboka wiara - zrazu spontaniczna i bezkrytyczna, wyniesiona jako dar z domu rodzinnego i stale utwierdzana w kontaktach z najbliższym otoczeniem ${ }^{5}$, a następnie coraz bardziej świadomie pogłębiana dzięki studiom teologicznym i filozoficznym, formacji seminaryjnej oraz osobistej drodze rozwoju duchowego. Druga cecha wspólna to równie głęboka miłość ojczyzny. Tu także ogromną rolę odegrało na początku wychowanie w rodzinie i w środowisku, gdzie patriotyzm był czymś naturalnym i oczywistym ${ }^{6}$, następnie poznawanie dziejów ojczystych połączone z przyswajaniem specyficznego ethosu polskości, wreszcie samodzielnie rozwijane poczucie odpowiedzialności za wspólny los rodaków. Trzecim elementem łączącym postawy i poglądy obu kapłanów był zdecydowanie krytyczny stosunek do narzuconego Polakom po II wojnie światowej ustroju socjalistycznego oraz do większości konkretnych form realizacji programu politycznego władz państwowych, podporządkowanych ideologicznym nakazom rządzącej partii - PZPR. Czwarty obszar, gdzie spotykały się aspiracje i dążenia Wyszyńskiego i Tischnera, to umiłowanie wolności w połączeniu z uporczywie podejmowanymi próbami - w miarę posiadanych środków i narzędzi działania - poszerzenia przestrzeni wolności społecznej i obywatelskiej Polaków wbrew totalitarnym tendencjom władzy państwowej. Ostatnie cechy, które tu wymienię (choć można byłoby jeszcze długo kontynuować tę listę) to odwaga cywilna i osobista, bezkompromisowość, determinacja i gotowość do poniesienia ofiary w służbie tym wartościom, które każdy z naszych bohaterów uważał za niezbędny warunek godnego życia w cywilizowanym, europejskim kraju.

5 „Przyszły prymas wychowywał się w tradycyjnym domu, w bardzo religijnej atmosferze. Ojciec Stefana długie godziny spędzał na kolanach, modląc się. [...] Obojgu rodzicom bliski był kult Matki Bożej. [...] To z domu rodzinnego wyniósł on silną pobożność maryjną. [...] Wiara Wyszyńskiego od dziecka była silna. Nigdy, jak mówił, nie miał związanych z nią wątpliwości”. E. K. Czaczkowska, Kardynał Wyszyński, Warszawa, s. 37, 39. Natomiast w rodzinie Tischnerów największym wzorem i autorytetem moralnym w dziedzinie wychowania religijnego był dziadek Józefa ze strony matki, Sebastian Chowaniec. Wojciech Bonowicz pisze o nim: „Był człowiekiem bardzo pobożnym, o jasnych zasadach etycznych. [...] w parafialnej księdze zgonów - w sierpniu 1954 - zapisano o nim: «długoletni śpiewak różańcowy w kościele św. Sebastiana w Jurgowie». [...] O dziadku z Jurgowa ksiądz Józef Tischner będzie mówił wielokrotnie, że uważa go za swój wzór: zadedykuje mu jeden z pierwszych artykułów opublikowanych na łamach Znaku”. W. Bonowicz, Tischner, Kraków 2001, s. 9 i 27.

6 „Religijność łączyła się w domu Wyszyńskich z silnym patriotyzmem. Gdy [...] językiem obowiązującym był rosyjski, w domu modlono się po polsku. Ojciec Stefana uczył dzieci polskiej historii i kultury [...]. Od ojca odebrał też późniejszy prymas pierwsze lekcje patriotyzmu, gdy nocą $[\ldots]$ porządkowali w okolicy groby powstańców styczniowych”. E. Czaczkowska, Kardynat Wyszyński, s. 37. 
Między Wyszyńskim a Tischnerem nie doszło nigdy do bezpośredniego dialogu - widocznie nie zaistniała taka potrzeba, choć była zapewne potencjalna gotowość z obu stron. Wytyczyli jednak w obrębie polskiego Kościoła dwie spośród wielu możliwych dróg, wyróżniające się siłą oddziaływania i trafnością oraz głębią stojących u ich źródeł przemyśleń. Spróbujmy się zastanowić, jak się układały owe drogi w stosunku do siebie. Nie było żadnej niechęci ani niezrozumienia między tymi, którzy je wyznaczali. Były natomiast różne optyki i czasami zdecydowanie różne preferencje, choć dotyczyły one wyłącznie środków do celu, który był w obu przypadkach zasadniczo ten sam.

W polskiej powojennej rzeczywistości należało przede wszystkim zdecydowanie przeciwstawić się ateistycznej propagandzie, zmierzającej do zepchnięcia religii na margines życia publicznego lub nawet do całkowitej laicyzacji społeczeństwa. Kolejnym, równie ważnym celem było pogłębienie indywidualnej wiary oraz zbudowanie mocnego fundamentu dla dojrzewania osobistej i wspólnotowej religijności Polaków. Zarówno Wyszyński, jak Tischner mieli całkowitą pewność, że naród polski ma szansę przetrwać trudny czas przymusowej indoktrynacji komunistycznej jedynie pod warunkiem dochowania wierności Bogu i nauczaniu Kościoła. Obaj wyraźnie dostrzegali liczne niebezpieczeństwa wynikające z przyjęcia modelu „nowego człowieka”, ukształtowanego w oparciu o ideały socjali$\mathrm{zmu}^{7}$. Nie ulegało wątpliwości, że chcąc bronić człowieka przed dehumanizacją, uprzedmiotowieniem i redukcją do wymiaru ekonomicznego, trzeba było bronić wiary i nadziei chrześcijańskiej.

Pozostawało pytanie, jakimi środkami należy się posłużyć dla realizacji owego celu. Tu już nie było jednomyślności. Przeciwnie, na tym polu ujawniają się zdecydowane różnice między zwolennikami dwóch koncepcji odrodzenia wiary. Z perspektywy czasu widać jednak, że nie tylko owa dwoistość optyk, ale w ogóle fakt istnienia $\mathrm{w}$ naszym kraju wielu różnych modeli religijności ${ }^{8}$ oraz stopniowo rosnąca otwartość na odmienne sposoby rozumienia i przeżywania doświadczenia wiary okazały się o wiele skuteczniejszą receptą na odparcie sekularyzacyjnych tendencji niż dokonywane w niektórych środowiskach kościelnych próby zwierania szeregów i rygorystycznego trzymania się jednej tylko wykładni katolickiej doktryny. Krajobraz duchowy polskiego katolicyzmu lat 60. i 70., dzięki swej

Jaki to miał być człowiek - zob. T. Ślipko, Pojęcie człowieka w świetle współczesnej antropologii marksistowskiej w Polsce, ,Zeszyty Naukowe KUL” 10, 1967, 2, s. 3-16; R. Grzybowski, Idea wychowania nowego czlowieka (homo sovieticus) i jej odzwierciedlenie w założeniach programowych Wszechzwiązowej Organizacji Pionierskiej, „Polska Myśl Pedagogiczna” 2018 nr 4, s. 297-322.

8 Np. Wiesław Przyczyna i Gerard Siwek wymieniają następujące odmiany katolicyzmu w Polsce: masowy, zamknięty, otwarty, integralny oraz katolicyzm protestu. Zob. W. Przyczyna, G. Siwek, Język w Kościele, w: Polszczyzna 2000. Orędzie o stanie języka na przełomie tysiacleci, red. W. Pisarek, Kraków 1999, s. 131. 
różnorodności, bogactwu barw i odcieni sprawił, że Kościół stał się stopniowo oazą wolności, miejscem spotkań i dialogu ludzi o bardzo różnej proweniencji i orientacji filozoficznej oraz światopoglądowej, a przede wszystkim miejscem formacji coraz bardziej dojrzałych i świadomych postaw chrześcijańskich ${ }^{9}$. Ważną częścią owego krajobrazu były przedstawiane tutaj dwa modele duchowości człowieka wiary, które wyłaniają się z refleksji intelektualnej i pracy duszpasterskiej Wyszyńskiego i Tischnera. Chciałbym przedstawić je po kolei, zwracając uwagę zarówno na różnice, jak podobieństwa między nimi.

\section{STEFAN WYSZYŃSKI - MĄDRA I WIERNA MIŁOŚĆ OJCZYZNY}

Stefan Wyszyński, urodzony 17 lat przed odzyskaniem niepodległości przez Polskę, od dziecka był wychowywany w tradycji romantyczno-patriotycznej i w kulcie maryjnym ${ }^{10}$. Wywodził się ze środowiska, w którym z nabożeństwem czytało się dzieła Mickiewicza i Słowackiego - przede wszystkim Pana Tadeusza, Króla Ducha oraz Księgi Narodu i Pielgrzymstwa Polskiego. Nietrudno się domyślić, jak wielką wagę przywiązywał późniejszy prymas do słów: „Ojczyzno moja, ty jesteś jak zdrowie; Ile cię trzeba cenić, ten tylko się dowie, Kto cię stracił”. Będąc już dorosłym, mógł z głębokim zrozumieniem, wynikającym z własnych doświadczeń, czytać dalsze słowa Mickiewiczowskiej inwokacji, mówiące o cudownym uzdrowieniu za wstawiennictwem Matki Bożej: „Panno święta, co Jasnej bronisz Częstochowy / I w Ostrej świecisz Bramie! Ty, co gród zamkowy / Nowogródzki ochraniasz z jego wiernym ludem! / Jak mnie dziecko do zdrowia powróciłaś cudem / ( - Gdy od płaczącej matki, pod Twoją opiekę / Ofiarowany martwą podniosłem powiekę; / I zaraz mogłem pieszo, do Twych świątyń progu

9 Józef Tischner wspominał: „w połowie lat siedemdziesiątych [...] doszło do bezpośredniego zetknięcia studentów i tego, co Kościół miał najlepszego - grupy kapelanów akademickich. [Potem] byli uczestnicy duszpasterstw akademickich zapełniali Kluby Inteligencji Katolickiej, a młodzi ludzie przychodzili na studia często mając za sobą kontakt z powstającym już ruchem oazowym księdza Franciszka Blachnickiego. Najbardziej odczuwalny przełom dokonywał się wśród młodych. [...] W problematykę duszpasterską weszły zagadnienia społeczne, problemy kultury, pojawiła się idea duszpasterstwa [...] uzupełniającego edukację o to, czego nie dają szkoły państwowe [...] my w Krakowie mieliśmy duszpasterstwa specjalistyczne - prawników, lekarzy, pracowników nauki [...] istniała koncepcja integrowania środowisk". Między panem a plebanem, s. 219, 225.

${ }^{10}$ „W domu Wyszyńskich [...] były książki religijne - Biblia, żywoty świętych, a także przyrodnicze, historyczne oraz literatura piękna - dzieła Mickiewicza i Kraszewskiego. [...] Przyszły prymas wychowywał się w tradycyjnym domu, w bardzo religijnej atmosferze. [...] Obojgu rodzicom bliski był kult Matki Bożej. [...] To z domu rodzinnego wyniósł on silną pobożność maryjną. [...] Religijność łączyła się w domu Wyszyńskich z silnym patriotyzmem. [...] Ojciec Stefana uczył dzieci polskiej historii i kultury”. E. K. Czaczkowska, Kardynał Wyszyński, s. 37. 
/ Iść za wrócone życie podziękować Bogu -) / Tak nas powrócisz cudem na Ojczyzny łono!"’11.

Należał do pokolenia, które dwukrotnie przeżyło cud zmartwychwstania ojczyzny. Po raz pierwszy w roku 1918, z radością i entuzjazmem po długich 123 latach narodowej niewoli; po raz drugi w 1945 - początkowo z porównywalną radością, płynącą z zakończenia trwającej blisko 6 lat hitlerowskiej okupacji. Tym razem jednak radość wkrótce zmieniła się w rozczarowanie, niepokój, może nawet gniew, gdyż ci, którzy wyparli Niemców z ziemi polskiej, okazali się pod wieloma względami niewiele lepsi.

Przez całe życie nosił w sercu idealną wizję narodu polskiego, ukształtowaną przez pokolenia czasów niewoli, opartą na lekturach romantycznych wieszczów, na kulcie bohaterów powstań narodowych i na powtarzanych cichym głosem marzeniach o wybiciu się na niepodległość. Jednak największy ciężar pracy duszpasterskiej i posługi związanej z coraz wyższymi funkcjami w hierarchii kościelnej przypadł na czas już po „drugim zmartwychwstaniu”, gdy Polska formalnie niepodległa i uznawana w skali międzynarodowej za suwerenne państwo - rządzona była przez siły polityczne, służalczo podporządkowane imperialnym interesom komunistycznej Rosji, niejednokrotnie rażąco sprzecznym z rzetelnie rozumianą polską racją stanu. W takiej rzeczywistości - bo inna była wówczas nie do pomyślenia - trzeba było żyć i działać, przyczyniając się w miarę swych możliwości do tego, by realnie istniejąca Polska stawała się możliwie podobna do tej idealnej i wymarzonej.

Stefan Wyszyński w niezwykle trafny sposób, świadczący o głębokiej umiejętności rozpoznawania znaków czasu, zrozumiał swoją rolę jako przywódcy i zarazem przewodnika całego Kościoła w Polsce w tamtych, wyjątkowo trudnych czasach. Mając na względzie kilkuwiekową rodzimą tradycję prymasów-interrek-

11 Tekst Mickiewiczowskiej inwokacji musiał mu być bliski - Andrzej Micewski przytacza następujące wspomnienie S. Wyszyńskiego: „Mój ojciec z upodobaniem jeździł na Jasną Górę, a moja matka do Ostrej Bramy [...] oboje odznaczali się głęboką czcią i miłością do Matki Najświętszej i jeżeli co na ten temat ich różniło - to wieczny dialog, która Matka Boża jest skuteczniejsza: czy ta, co w Ostrej świeci Bramie, czy ta, co Jasnej bronisz Częstochowy”. Cyt. za: A. Micewski, Kardynat Wyszyński prymas i mąż stanu, Paryż 1982, s. 17. W roku 1924 - roku ukończenia seminarium duchownego i uzyskania święceń kapłańskich - przyszły prymas także gorliwie zabiegał u Matki Bożej o łaskę uzdrowienia z ciężkiej choroby. Jak opisuje Ewa Czaczkowska, „przez cały okres studiów [seminaryjnych] Wyszyński chorował na gruźlicę, która odzywała się jeszcze przez wiele lat. [...] poważnie zaniemógł także tydzień przed święceniami kolegów, pod koniec czerwca $1924 \mathrm{r}$. Trafił do szpitala z silnym zapaleniem płuc. [...] Mszę prymicyjną odprawił 5 sierpnia na Jasnej Górze. [...] Przez dłuższy czas każdego dnia, gdy odprawiał mszę świętą, wydawało mu się, że czyni to po raz ostatni. Modlił się, aby być księdzem chociaż przez rok. A po pół wieku od święceń mówił: «I wydaje mi się, dzieci Boże, że stawiając wszystko na Bogurodzicę, nie zostałem zawiedziony»”. E. K. Czaczkowska, Kardynat Wyszyński, s. 44. 
sów ${ }^{12}$, świadomie wziął na swe barki ciężar historycznej odpowiedzialności za duchowe i moralne oblicze narodu, poddanego po raz kolejny trudnej dziejowej próbie. Wiedział, że od jego postawy i od tego, jak pokieruje polskim Kościołem, zależy bardzo wiele ${ }^{13}$. W drugiej połowie lat 50 . nastał w jego życiu czas przełomowej próby. Gdyby wtedy on osobiście zawiódł, cały polski Kościół i polski katolicyzm znalazłby się w sytuacji ekstremalnie trudnej. Na szczęście prymas sprostał historycznemu wyzwaniu i nie ugiął się przed komunistycznym terrorem, pod naporem którego zmuszony był ponad trzy lata spędzić w czterech kolejnych ośrodkach internowania ${ }^{14}$, narażony na utratę zdrowia, poddawany nieustannej presji psychicznej i licznym szykanom. Trudny czas internowania wykorzystał na pogłębienie własnej wiary ${ }^{15}$, ale przede wszystkim na szczegółowe opracowanie programu duszpasterskiego na najbliższe dziesięciolecie, poprzedzające historyczną rocznicę tysiąclecia chrztu Polski ${ }^{16}$.

Program ów opierał się na założeniach, które wynikały z najgłębszych przekonań dotyczących tego, jak najlepiej kształtować religijność narodu w czasach dziejowej próby. Wyszyński wierzył głęboko, że do Polaków najsilniej przemówi odwołanie się do tradycji i obyczaju przodków, przypomnienie wzniosłych wydarzeń z dziejów ojczystych, sięgnięcie po wyraziste symbole o patriotycznej i religijnej treści oraz obudzenie sumienia każdego wierzącego Polaka poprzez konfrontację z największymi i najbardziej rozpowszechnionymi narodowymi wadami. Chciał wychowywać „nowych ludzi plemienia”"17 w poczuciu ciągłości tradycji narodowej i religijnej, odpowiedzialności za dziedzictwo przeszłości, wierności

12 Zob. J. Pietrzak, Przywileje i godności Prymasów Polski, „Studia Prymasowskie” 2011, nr 5, s. $57-98$.

13 „Świadomość zagrożenia dla religijnej tożsamości i narodowej spójności Polski przez polityczną i kulturową ofensywę komunizmu jest dla kardynała wyzwaniem cywilizacyjnym. Postulat jedności narodu wyraża pragnienie ocalenia Polski przed katastrofą dziejową, którą krótko po objęciu urzędu prymasowskiego abp Wyszyński prawidłowo diagnozował na podstawie wnikliwej, popartej faktami analizy intencji władz komunistycznych. Od początku swej posługi brał na siebie odpowiedzialność za losy Kościoła i Ojczyzny". A. Wierzbicki, Piastowski Wyszyński, jagielloński Wojtyła. Dwie chrześcijańskie interpretacje polskości, „Więź” 2017, nr 5. Tekst dostępny online: https://wiez.pl/2017/05/05/piastowski-wyszynski-jagiellonski-wojtyla-dwie-c hrzescijanskie-interpretacje-polskosci/ (1.10.2021).

14 W Rywałdzie Szlacheckim od 26 września do 12 października 1953, Stoczku Warmińskim od 12 października 1953 do 6 października 1954, Prudniku od 6 października 1954 do 29 października 1955 i Komańczy od 29 października 1955 do 28 października 1956. Zob. https://muzhp. $\mathrm{pl} / \mathrm{pl} / \mathrm{e} / 1661 /$ internowanie-prymasa-wyszynskiego (1.10.2021).

15 Zob. Z. J. Kijas, Wyszyński. Narodziny nowego człowieka, Warszawa 2021, s. 23-38.

16 Zob. M. Okońska, Wszystko postawił na Maryję, Warszawa 2017.

17 „Prymas Stefan Wyszyński [...] wiedział, że naród, który porzuca Boga, zrywa z dziedzictwem przeszłości, ulega demoralizacji i niszczy rodzinę, nie jest zdolny do życia w niepodległości. Dlatego wytyczona przez niego droga wyzwolenia z komunistycznej zależności wiodła przez ukształtowanie - jak powtarzał - «nowych ludzi plemienia». [...] Warunkiem realnej odnowy jest obudzenie sumień, do czego nieustannie nawoływał". J. Szarek, Duszpasterz i mąż stanu. 
wobec zwyczajów i praktyk religijnych kultywowanych przez przodków. Mieli to być zarazem ludzie silni duchowo i moralnie, zdolni do przeciwstawienia się z jednej strony własnym grzechom, a z drugiej - do nieulegania demoralizującym podszeptom komunistycznej propagandy.

Aby wszystkim przybliżyć własną wizję idealnej Polski, budował swe przesłanie na nośnych, czytelnych i powszechnie zrozumiałych symbolach. Jako że jego wyobraźnia oraz wrażliwość religijna i narodowa ukształtowane były na symbolach zaczerpniętych z głównego nurtu polskiego Romantyzmu, widział swój naród jako „lawę” pełną wewnętrznego ognia ${ }^{18}$. Równocześnie bliska mu była idea bohatera romantycznego jako jednostki „,cierpiącej za miliony”19 i za cenę osobistego cierpienia nabywającej prawo do moralnego przywództwa narodu. W świetle tej romantycznej wizji można postrzegać samego prymasa jako taką właśnie jednostkę, noszącą (od czasu trzyletniego internowania) stygmaty cierpienia za wiarę i naród, prowadzącą miliony wierzących Polaków w stronę moralnego i religijnego odrodzenia całego narodu pod skrzydłami Kościoła ${ }^{20}$. Narzędziem tej odnowy miało być (i rzeczywiście się stało) silne i przyciągające swą atrakcyjnością imaginarium społeczne, zbudowane na porywających polskie serca symbolach. Były nimi: chrzest pierwszego władcy narodu, rozpoczynający tysiącletnią tradycję nieprzerwanej wierności Chrystusowi, wielki zryw Polaków w obronie wiary i ojczyzny podczas potopu szwedzkiego, w obliczu groźby profanacji Najświętszego Obrazu NMP Jasnogórskiej, i idąca w ślad za nim tradycja szczególnego kultu maryjnego na ziemiach polskich, symbolizowana pamiętnym aktem Ślubów Lwowskich króla Jana Kazimierza w 1656 roku.

Charakterystyczną cechą owych symboli jest fakt, że jedno wydarzenie i jedna centralna postać (w przypadku chrztu z 966 r. był nią Mieszko I, uosobieniem obrońców Jasnej Góry stał się przeor Augustyn Kordecki, a szczególny kult

Czterdziesta rocznica śmierci kardynała Stefana Wyszyńskiego, Bezpłatny dodatek do „Gościa Niedzielnego", 23 maja 2021, s. 2.

18 „Nasz naród jak lawa, / Z wierzchu zimna i twarda, sucha i plugawa, / Lecz wewnętrznego ognia sto lat nie wyziębi; / Plwajmy na tę skorupę i zstąpmy do głębi”. A. Mickiewicz, Dziady. Część III, w: Dzieła. Tom III. Utwory dramatyczne, Warszawa 1955, s. 210.

19 „Nazywam się Milijon - bo za milijony / Kocham i cierpię katusze. / Patrzę na ojczyznę biedną, / Jak syn na ojca wplecionego w koło; / Czuję całego cierpienia narodu, / Jak matka czuje w łonie bóle swego płodu". A. Mickiewicz, Dziady. Część III, s. 166.

20 Alfred Wierzbicki pisze o Stefanie Wyszyńskim: „Lektura Zapisków więziennych pozwala zrozumieć, jak głęboko identyfikował swój los z cierpieniem Chrystusa oraz z cierpieniami narodu. [...] Jeśli uświadomimy sobie fizyczne, społeczne i kościelne odosobnienie prymasa Polski w latach uwięzienia i jednocześnie głębię jego związku z narodem, możemy dojrzeć w nim kogoś podobnego do Mickiewiczowskiego Konrada, który cierpi za miliony. Romantyczny paradygmat utożsamienia losu wybitnej jednostki - w tym przypadku faktycznej głowy Kościoła w Polsce z losem całego narodu jest również kluczem do rozumienia ścisłej więzi narodu i Kościoła, jaką głosił polski hierarcha.”. A. Wierzbicki, Piastowski Wyszyński, jagielloński Wojtyła. Dwie chrześcijańskie interpretacje polskości. 
maryjny kojarzy się z osobą Jana Kazimierza), mobilizuje całą wspólnotę do zmaksymalizowania wysiłku na rzecz realizacji wielkiej idei, każdorazowo ufundowanej na kulcie religijnym. Równocześnie było w tych Prymasowskich przekonaniach i planach dużo romantycznej wiary w niespożytą siłę odwiecznej ludzkiej natury, w naturalną mądrość ludu, w potęgę historycznego dziedzictwa, ale i w prymat ducha wspólnoty nad wybujałym indywidualizmem. Program duszpasterski Wyszyńskiego był wyraźnie zorientowany na przewagę form masowej pobożności ${ }^{21}$, dlatego poszukiwał nośnych i możliwie prostych form przekazu, zrozumiałych dla każdego Polaka.

Mając tę świadomość, prymas dopracowywał się w swym programie duszpasterskim „ogólnych zasad istnienia i działania Kościoła świętego w naszej ochrzczonej Ojczyźnie, na nasze życie i współpracę ludu Bożego z tą rzeczywistością, w jakiej Bóg dopuścił, abyśmy żyli i pracowali, przyczyniając się do pokoju Chrystusowego w Rodzinie Bożej"22. Nie przypadkiem padają w cytowanym tekście, datowanym na styczeń 1980 roku, słowa „ochrzczona Ojczyzna”. Świadczą o tym, że program duszpasterski Wielkiej Nowenny, zaplanowany na lata poprzedzające tysiąclecie chrztu Polski, nie był tylko okazjonalnym uczczeniem okrągłego jubileuszu, lecz rezultatem trwałego zespołu przekonań o stricte filozoficznym charakterze. Dlaczego Wyszyński mówił konsekwentnie o chrzcie Polski, a nie o chrzcie księcia Polan Mieszka I? Dlaczego mówił „ochrzczona Ojczyzna”, a nie „Ojczyzna ludzi ochrzczonych”? Ponieważ dostrzegał głęboki, duchowy związek między trwającą nieprzerwanie od tysiąca lat wiernością wierze katolickiej, a polską tożsamością narodową: Polonia semper fidelis. Jedną z najważniejszych trosk prymasa było przeto ocalenie ciągłości funkcjonowania Kościoła w warunkach agresywnej, ateistycznej ideologii narzucanej przez aparat państwowy i propagandowy, w połączeniu z szykanami i prześladowaniami katolików, które nie ominęły również jego osoby ${ }^{23}$.

Stefan Wyszyński był przekonany, że naród polski pozbawiony wiary oraz możliwości korzystania z duchowej posługi Kościoła utraci swoją tożsamość i ulegnie głębokiej demoralizacji. Ze wszystkich sił starał się temu zapobiec, stosując różne metody i nie stroniąc nawet od dyplomatycznych prób zawierania

${ }^{21}$ „Prymas postawił w Wielkiej Nowennie na szerokie masy wierzących w przekonaniu, że tylko oni mogą stać się żywą tamą, która zatrzyma rozlewanie się bezbożnictwa. Dlatego postawił na rozwijanie bliskich ludowi form pobożności, czyli na tzw. pobożność masową, której ważnym elementem jest kult maryjny z jego uczuciowością oraz przywiązanie do wiary ojców". E. K. Czaczkowska, Zwycięski plan-jedność i katolicyzm masowy, „Rzeczpospolita”27.05.2011, artykuł dostępny w internecie: https://www.rp.pl/artykul/664230-Zwycieski-plan---jednosc-i--katolicyzm-masowy.html (1.10.20210.

22 S. Wyszyński, 2. Kazanie Świętojańskie Prymasa Polski, Poznań-Warszawa 1980, s. 3.

23 Mowa o internowaniu prymasa w latach 1953-1956 oraz o niezliczonych incydentach nękania go i nachodzenia przez funkcjonariuszy służb bezpieczeństwa PRL. Zob. J. Eisler, Czterdzieśsi pięć lat, które wstrząsnęty Polską. Historia polityczna PRL, Warszawa 2018, s. 151-154. 
wątpliwego moralnie kompromisu z komunistyczną władzą ${ }^{24}$. Jako wytrawny dyplomata, publicznie nie wypowiadał się otwarcie przeciwko władzy państwowej i narzuconemu Polsce ustrojowi, lecz zarazem wielokrotnie, ostro i zdecydowanie piętnował konkretne decyzje i posunięcia tej władzy ${ }^{25}$. Swoje przesłanie kierował jednak przede wszystkim pod adresem ochrzczonych Polaków, żyjących w nieprzyjaznym Kościołowi, socjalistycznym państwie. Państwo to - niezależnie od konkretnej formy ustrojowej - było jednak odrodzonym po niewoli i okupacji państwem polskim. Należało więc mu służyć, pracować na jego rzecz, przyczyniać się do dobrobytu ekonomicznego i dobrostanu psychicznego jego obywateli, lecz w taki sposób, by nie sprzeniewierzyć się wielowiekowej tradycji budowania ethosu polskości na fundamencie wiary i Ewangelii.

Prymas wiedział doskonale, że nie wszyscy Polacy są ochrzczeni, a i wśród tych, którzy uważają się za katolików, nie wszyscy biorą aktywny udział w życiu Kościoła, którym kierował. Uważał się jednak za powołanego przede wszystkim do tego, by wszystkim świadomym i zaangażowanym polskim katolikom wskazywać najlepszą drogę do budowania pomyślności ojczyzny w pokojowej współpracy z pozostałymi obywatelami. Do tych pierwszych mówił: „czuwajcie nad tym, aby wasze prawa były uszanowane, ale uszanowanie praw waszych zacznij-

24 „Po tym jak komunistyczne władze wypowiedziały we wrześniu 1945 r. konkordat, sytuacja Kościoła stała się bardzo trudna, bo jego prawa nie były zabezpieczone żadnymi umowami. [...] Prymas Stefan Wyszyński stał na stanowisku, że należy doprowadzić do zawarcia umowy, która określi sytuację Kościoła w powojennej rzeczywistości, by mógł przetrwać. [...] Episkopat Polski podpisał 14 kwietnia 1950 r. porozumienie z komunistycznym rządem. Ugoda od razu wzbudziła kontrowersje, jako zbyt daleko posunięte ustępstwo Kościoła wobec komunistów". Ł. Marek, Kompromis w pewnych granicach. Porozumienie państwo-Kościół z 1950 roku. Tekst dostęny online: https://krakow.ipn.gov.pl/p14/edukacja/przystanek-historia/95442,Kompromisw-pewnych-granicach-Porozumienie-panstwo-Kosciol-z-1950-roku.html (1.10.2021]) Po raz drugi poważne zarzuty wysuwano przeciw prymasowi po jego - zbyt ostrożnym i kunktatorskim zdaniem niektórych krytyków - wystąpieniu na Jasnej Górze 26 sierpnia 1980 r., podczas fali strajków trwających w całym kraju. Anna Rastawicka pisze: „Wszyscy z niepokojem oczekiwali, co powie Ksiądz Prymas na sumie [...]. Protestujący spodziewali się, że Prymas publicznie ich poprze. Władze oczekiwały, że uspokoi napiętą sytuację w kraju. Ksiądz Prymas [...] nie popierał ani rządu, ani strajków [...]. Do dzisiaj niektórzy biografowie, powierzchownie oceniając tę sytuację, piszą, że [...] to był błąd kardynała Wyszyńskiego. A jednak to nie był błąd, ale wyraz odpowiedzialności za cały naród, znak dojrzałej mądrości i intuicji opartej na znajomości historii i bolesnych doświadczeń”. A. Rastawicka, Ten zwycięża, kto miłuje, s. 265.

25 „Ksiądz Prymas nigdy nie milczał, gdy widział krzywdę robotników i nadużycia władzy. [...] Upominając się o prawa robotników, wielokrotnie rozmawiał z przedstawicielami najwyższych władz państwowych [...]. Po wypadkach grudniowych na Wybrzeżu w 1970 roku [...] piętnował zamordowanie niewinnych robotników, zwrócił się ze słowami braterskiego współczucia do wszystkich rodzin przeżywających ból po stracie najbliższych. Jednocześnie prosił: - Nie oskarżajcie, przebaczajcie, współczujcie, dzielcie się chlebem, nie traćcie nadziei, nie opuszczajcie rąk". Tamże, s. 262-263. 
cie od poszanowania praw innych ludzi z waszego otoczenia. [...] W największych trudnościach doniosłą rzeczą jest zachowanie ducha pokoju i miłości”"26.

Hierarchia wartości, którą autor Kazań Świętojańskich ${ }^{27}$ buduje dla swych słuchaczy, prezentuje się następująco: „Zasadnicze elementy [...], które wchodzą w życie ludzkie, to: Bóg - uznany i umiłowany; człowiek - uszanowany; ziemia ojczysta - obsłużona; władza na ziemi - sprawowana w miłości, sprawiedliwości i prawdzie. [...] Te istotne czynniki są warunkiem harmonii i pokoju świata"28.

Wyszyński był przekonany, że wiara i etyka chrześcijańska, oparte na fundamencie zawierzenia Bogu, są najlepszym fundamentem życia społecznego, również w pluralistycznej wspólnocie - pod warunkiem wzajemnego szacunku i przestrzegania zasad pokojowego współżycia oraz przy zachowaniu prawa do posiadania przez ludzi własnych przekonań, zwłaszcza religijnych. Pisał: „Bóg uznany i umiłowany - to znaczy: pokój z Bogiem i Kościołem. To początek pokonywania trudności w życiu narodów i w naszej Ojczyźnie [...] najważniejszym czynnikiem w ekonomii narodowej, mającym moc uleczenia jej, jest etyka, moralność chrześcijańska" ${ }^{29}$. Głosił dalej, że drugim fundamentem udanego życia społecznego we wspólnocie narodowej jest personalistyczna zasada szacunku dla każdej osoby ludzkiej, niezależnie od jej walorów, zdolności, umiejętności czy przydatności dla jakichkolwiek celów: „Trzeba więc uznać wysoką godność człowieka [...], jego znaczenie dla rodziny i narodu. Człowiek nie może być przedmiotem takiej czy innej polityki [...] ale ma wartość niezależną od ustroju, bo jego wartość wywodzi się z Boga samego. [...] Wsłuchując się w programy polityczne, z radością stwierdzamy, że [...] mówi się wreszcie o człowieku i o rodzinie" ${ }^{30}$. Za trzeci fundament uważał patriotyzm czynu, wyrażający się w konkretnych działaniach na rzecz ziemi ojczystej, jej zasobów i jej mieszkańców. Przypominał słuchaczom: „Człowiek dopiero na własnej ziemi jest we właściwym, normalnym klimacie ładu i myślenia społecznego. Jest w tym pewne misterium natury przyrodzonej, społecznej, socjologicznej i psychologicznej, że człowiek dąży do swojej ziemi, szuka jej i kocha ją. Kocha tak mocno, jak mieliśmy tego dowody w czasie ostatniej wojny" ${ }^{31}$. Czwarty fundament - to władza, która z miłością i w prawdzie służy narodowi, a nie przeciwstawia się jego najżywotniejszym interesom. O takiej, wyczekiwanej z nadzieją, władzy pisał: „Sprawować władzę, czyli rządzić [...]

26 S. Wyszyński, 2. Kazanie Świętojańskie, s. 22.

27 Opublikowane zostały dwa kazania, które prymas Wyszyński wygłosił w Katedrze p. w. św. Jana Chrzciciela w Warszawie: pierwsze z datą 6.01.1978, zatytułowane Duch Ewangelii w życiu społeczno-zawodowym i publicznym, i drugie, z datą 6.01.1980, zatytułowane Harmonia Bożo-ludzka w Polsce. Cytaty pochodzą z drugiego kazania.

28 Tamże, s. 4-5.

29 Tamże, s. 7-8.

30 Tamże, s. 10-11.

31 Tamże, s. 13. 
to znaczy służyć wszystkim od szczytu aż do dołu. Jest to możliwe tylko z pomocą miłości. [...] Tylko wtedy może być prawidłowa służba, gdy ludzie sprawujący władzę kierują się wrażliwością na człowieka i miłością"32.

Prymas Stefan Wyszyński w swych wypowiedziach wielokrotnie dawał wyraz osobistego zaangażowania i zatroskania o obecną kondycję narodu oraz jego przyszłość. Zdawał sobie sprawę, że los Polski spoczywa w ogromnej części w rękach samych Polaków. Wiedział, że aby uniknąć wewnętrznych i zewnętrznych zagrożeń, potrzebna jest wytrwała i wytężona praca, którą należy mądrze pokierować, by nie poszła na marne. Dlatego świadomie dążył do tego, by stojąc na czele Kościoła w Polsce budować swój wizerunek jako ojca narodu ${ }^{33}$, a nie wyniosłego i nieprzystępnego hierarchy, dalekiego od codziennych spraw zwykłych ludzi. Takim go zapamiętaliśmy; ta jego postawa sprawiła, że nauczanie wzmocnione osobistym świadectwem oraz żywą więzią z licznymi środowiskami, z którymi się na co dzień spotykał, przyniosło rzeczywiste i wymierne owoce w duszach wielu Polaków.

\section{JÓZEF TISCHNER - OJCZYZNA: WYBÓR, WOLNOŚĆ, WIERNOŚĆ}

W jednym z niedawno odnalezionych i opublikowanych tekstów Józef Tischner pisze o dwóch modelach patriotyzmu posiadających romantyczną genezę, wywodzących się od Mickiewicza i od Norwida: „W polskiej myśli istniały jakby dwa sposoby widzenia ojczyzny. Jedno wiąże się z Adamem Mickiewiczem, z ruchem Andrzeja Towiańskiego. Jest to tendencja do jej idealizowania. Ojczyzna jest wspaniała, piękna. [...] Ale jednocześnie pojawia się Norwid [...], który pokazuje tę Polskę od strony krytycznej. Nie można kwestionować patriotyzmu Norwida, a z drugiej strony nie można Norwida oderwać od tego niesłychanego krytycyzmu wobec Polski. I on, kiedy ma zdefiniować ojczyznę, mówi: 'Bo ojczyzna, rodacy, to jest moralne zjednoczenie, bez którego partyi nawet nie ma, bez którego partie są jak koczowiska polemiczne, których ogniem niezgoda, a rzeczywistością dym wyrazów'. Każde to słowo wymaga skupionej refleksji. [...] Patrząc [z dzisiejszej] perspektywy na Polskę, widzimy, jak się sprawdzają słowa Norwida"34. O ile Stefana Wyszyńskiego można (bez obawy popełnienia błędu) identyfikować z patrio-

32 Tamże, s. 16-17.

33 „Z racji pełnionego urzędu uważał się za ojca duchowego wszystkich Polaków, również «braci komunistów», także tych «w stalowych mundurach», czyli funkcjonariuszy Milicji Obywatelskiej”. Cz. Ryszka, Prymas Wyszyński. Ojciec Ojczyzny, Kraków 2020. Cytuję za: https://dzieje. $\mathrm{pl} /$ ksiazki/prymas-wyszynski-ojciec-ojczyzny (1.10.2021).

34 J. Tischner, Ojczyzna - o co tutaj chodzi?, w: tegoż, Nadzieja mimo wszystko, Wybór i oprac. W. Bonowicz, Kraków 2020, s. 92-94. Zacytowany w tym tekście (z drobnymi zmianami) fragment prozy Norwida pochodzi z dzieła: Glos niedawno do wychodźstwa polskiego przybyłego artysty, w: C. K. Norwid, Pisma polityczne i społeczne, Warszawa 1983. 
tyzmem Mickiewiczowskim, o tyle Józefowi Tischnerowi zdecydowanie bliższy jest model Norwidowski ${ }^{35}$. Pociąga to za sobą daleko idące konsekwencje.

W myśleniu Józefa Tischnera nie zaznacza się tak silny związek między wiarą a patriotyzmem, jak u prymasa Wyszyńskiego. Ojczyznę rozumie on - za Norwidem - jako „moralne zjednoczenie”36 wszystkich Polaków ponad podziałami religijnymi i światopoglądowymi. Precyzuje swój pogląd następująco: „Ojczyzna to jest coś głębszego [...] coś bardziej podstawowego. [...] Widzieć tę ojczyznę jako zjednoczenie moralne, potem móc się różnić w tej ojczyźnie. [...] Jeden może wierzyć, drugi nie wierzyć, modlić się, nie modlić się, jeden może wierzyć w Jahwe, drugi w Chrystusa, ale moralne zjednoczenie to jest klucz"'37.

Jak rozumieć to kluczowe pojęcie? Najprościej - jako poszanowanie zasadniczo tego samego systemu wartości. Dla Tischnera bowiem nie ulega wątpliwości, że życie społeczne człowieka opiera się na byciu wobec wartości, które kształtują przestrzeń międzyludzkich obcowań ${ }^{38}$. Nie znaczy to, że cały układ wartości, tworzących Ja Aksjologiczne ${ }^{39}$ poszczególnych Polaków, musi się bezwzględnie pokrywać (taki wymóg byłby całkowicie nierealny, w dodatku niebezpiecznie podobny do Orwellowskiej wizji społeczeństwa). Musi jednak istnieć pewna wspólna płaszczyzna aksjologiczna, wyznaczająca moralny sens patriotyzmu. Dla uniknięcia nieporozumień trzeba tu wyjaśnić, że słowo „musi” nie oznacza żadnego przymusu moralnego. Taka koncepcja, w której patriotyzm sprowadzałby się do postawy „kocham, bo muszę”, jest dla Tischnera nie do przyjęcia. W swoich licznych wypowiedziach kładł on ogromny nacisk na element wolności wyboru tych wartości, które podmiot identyfikuje z Ojczyzną. Oto przykład: „Ojczyzna-Polska

35 Jeszcze jednym potwierdzeniem tej tezy jest następująca wypowiedź ze wstępu do książki Polski młyn (zwanej niekiedy „najbardziej patriotyczną książką Tischnera”): „My, Polacy, przechodzimy przez niezwykle trudną próbę historii. Trzeba wyciągnąć z niej wnioski. [...] Mówi się o nas, że jesteśmy skazani na patriotyzm. [...] Motyw patriotyzmu przewija się w różnym nasileniu przez całą książkę. [...] Materiałem przemyśleń jest najpierw nasza historia, a w niej myśl Cypriana Kamila Norwida, który jest niewyczerpaną kopalnią patriotycznych pojęć". J. Tischner, Polski młyn, Kraków 1991, s. 7. O swej fascynacji Norwidem i jego wizją polskości mówił także w rozmowie z Jackiem Żakowskim i Adamem Michnikiem: „obserwuję pojawianie się w moim życiu różnych, zrazu nieskrystalizowanych, pozornie nieistotnych wątków, nieoczekiwanie owocujących po wielu latach. [...] Wątek norwidowsko-narodowy też jakby drzemał latami. Powstał w końcu lat sześćdziesiątych, a w latach osiemdziesiątych zaowocował tekstem Polska jest ojczyzna, formułującym współczesne odczytanie Norwidowskiej wizji patriotyzmu". Między panem a plebanem, s. 132.

36 Zob. J. Tischner, Nadzieja mimo wszystko, s. 93.

37 Tamże, s. 94-95.

38 Zob. tenże, Filozofia dramatu, Kraków 1998 s. 267-295.

39 „Wśród wielu możliwych i faktycznie przeżywanych doświadczeń własnego Ja, doświadczenie Ja jako pewnej swoistej wartości (aksjos) jest doświadczeniem najbardziej podstawowym. Konsekwentnie oparte o to doświadczenie pojęcie Ja Aksjologicznego jest tym pojęciem, z którego dają się wywieść wszystkie inne pojęcia Ja”. Tenże, Świat ludzkiej nadziei, Kraków 1975, s. 163. 
nie jest wytworem jakiejś dziejowej konieczności, lecz dziełem wolności [...] nie ma konieczności Polski-Ojczyzny [...] jednak wciąż wybiera się polskość, wciąż uznaje za swoją własność, wciąż znajdują się tacy, którzy się do niej przyznają [...] to znaczy, że u podłoża ojczyzny znajduje się wybór, a u podłoża wyboru wolność. Owocem wolności i wyboru jest zaś wierność. [...] Wierność buduje się z pamięci o przeszłości i z wiary w przyszłość. Jest przekonaniem, że wartości, które przeszły już próbę czasu, mają prawo być. Wartością taką jest Polska-Ojczyzna"40

Wierna miłość ojczyzny zobowiązuje każdego do tego, by wszelkie, mniej ważne sprawy i cele podporządkować nadrzędnemu celowi, jakim jest dobro ojczystego kraju. Można do tego celu podążać różnymi drogami. Nie trzeba jednak przeprowadzać zbyt wnikliwej analizy, by dostrzec, że wszystkie konkretne wskazówki, jakie Tischner formułuje pod adresem swoich rodaków ${ }^{41}$, mają swe źródło w zasadach wiary i moralności chrześcijańskiej.

Najlepiej da się to pokazać na przykładzie Etyki solidarności (którą - jako program radykalnej odnowy moralnej narodu - można byłoby porównać z Wielką Nowenną Stefana Wyszyńskiego). Tischner stawia tam przed sobą i przed wszystkimi odbiorcami tekstu podstawowe zadanie, które - w metaforycznym języku przekazu, wynikającym z narzuconej przez kontekst potrzeby ${ }^{42}$ - prezentuje się następująco: „Trzeba zrobić porządek w domu. Właśnie to, co trzeba zrobić, zespala i pobudza do czynu. Zespala głębiej niż strach przed wrogami. Chcemy być narodem zespolonym, ale nie zespolonym strachem. Chcemy, aby nas jednoczył najprostszy, ludzki obowiązek" ${ }^{43}$.

Zanim pójdziemy dalej z analizami, warto pokrótce zwrócić uwagę na dwa charakterystyczne elementy przytoczonej wypowiedzi. W jej pierwszym zdaniu widoczne jest wyraźne nawiązanie do Mickiewiczowskiej wersji patriotyzmu: ucho Polaka bezbłędnie wychwyci tu echo sceny z Pana Tadeusza, w której Ksiądz Robak zagrzewa szlachtę do patriotycznego czynu ${ }^{44}$. Nie jest więc do końca tak,

40 Tenże, Nadzieja mimo wszystko, s. 80-85.

41 W dorobku Tischnera można wskazać wiele tekstów poświęconych bezpośrednio kwestii poszukiwania dróg do lepszej przyszłości Polski. Są to na przykład: Polski kształt dialogu, Paris 1981; Polska spowiedź roku 1982, w: Na drogach krzyżowych historii, Kraków 1982, s. 1-36; Polski czas nawiedzenia, tamże, s. 38-66; W kręgu filozofii pracy, Kraków 1983; Polska jest Ojczyzna, Paris 1985; Polski młyn, Kraków 1991 i in.

42 Trzeba bowiem pamiętać, że pierwszy rozdział książki Etyki solidarności, zatytułowany Solidarność sumień, jest zapisem kazania wygłoszonego na Wawelu podczas mszy w dniu 19 X 1980 roku.

43 J. Tischner, Etyka solidarności, Kraków 1981, s. 7.

44 „Więc nie dość gościa czekać, nie dość i zaprosić, / Trzeba czeladkę zebrać i stoły pownosić, / A przed ucztą potrzeba dom oczyścić z śmieci; / Oczyścić dom, powtarzam, oczyścić dom, dzieci!", A. Mickiewicz, Pan Tadeusz, Księga czwarta. Dyplomatyka i łowy, tekst dostępny online: http://www.lektury.waw.pl/77/78/pan-tadeusz (1.10.2021). 
że z owych dwóch wzorców miłości ojczyzny zawsze bliższy Tischnerowi był ten Norwidowski ${ }^{45}$. I druga uwaga: widać, z jaką konsekwencją Tischner przyjmuje i próbuje wcielać w życie ideę ojczyzny jako „moralnego zjednoczenia”, tu wyrażoną w słowach: „naród zespolony przez najprostszy, ludzki obowiązek”.

Apel o „porządek w domu” nie pozostaje gołosłowny. W ślad za nim następują konkretne wskazania moralne, w jaki sposób i w jakich obszarach życia społecznego Polacy muszą spełnić swój obowiązek. Będą to kolejno: wspólnota, dialog, praca, cierpienie, nauka, sztuka, demokracja, władanie, gospodarowanie, wychowanie, rodzina, ojczyzna. Pomiędzy nimi znajdują się rozdziały o nieco innym charakterze - pokazujące negatywne, domagające się przezwyciężenia cechy obecnej rzeczywistości społecznej, a wśród nich: wyzysk, iluzja, zdrada ${ }^{46}$.

Trzeba tu podkreślić jeszcze jeden symptomatyczny rys Tischnerowskiego programu ,moralnego zjednoczenia narodu” wokół idei solidarności: wszystkie wartości, których realizacja ma służyć dobru ojczyzny, wyprowadzone są w sposób nie budzący wątpliwości z jednego źródła - z Ewangelii. Fakt ten został zapowiedziany już w pierwszym, otwierającym książkę rozdziale: „Przynosimy dziś na Wzgórze Wawelskie nasze najbliższe sercu sprawy. [...] Naprzeciw nam wyszła Ewangelia Chrystusowa, czyli Dobra Nowina. O czym mówi nam dziś [...]? Mówi o jednym: o sile wiary i modlitwy. [...] Gdyby trzeba było jakoś bliżej określić znaczenie słowa solidarność, to należałoby sięgnąć do Ewangelii i tam szukać jego rodowodu" ${ }^{\prime 7}$.

Taki jest więc - nieco odmienny, lecz bynajmniej nie rozbieżny w stosunku do prymasa Wyszyńskiego - kształt relacji między wiarą a ojczyzną w refleksji Józefa Tischnera. Kolejny temat wymagający rozpatrzenia to funkcja symboli w myśleniu o sprawie polskiej. Zostało już pokazane, że Wyszyński w swym programie duszpasterskim chętnie sięgał po symbole - zwłaszcza takie, które jednoznacznie kojarzyły się z najpiękniejszymi kartami dziejów narodu. Skłonność do operowania symbolami ujawnia się miejscami również u Tischnera; jednak zestawienie owych symboli z tymi, do których odwoływał się prymas, odsłania ogromną różnicę. Dla Wyszyńskiego symbol funkcjonował jak sztandar, pod którym skupiają się wszyscy, dla których bliskie są wskazywane przezeń wartości, a którzy czują

45 Podobnie jak nie jest prawdą, że prymas Wyszyński nie odwoływał się w swym nauczaniu do myśli Norwida - jako przykład może posłużyć kazanie wygłoszone na Jasnej Górze 15 września 1968 r., w którym prymas cytuje i komentuje wiersz Norwida Litania. Zob. S. Wyszyński, Kocham Ojczyznę więcej niż własne serce. Wybór tekstów, red. B. Dembińska, Częstochowa 2020, s. 30-33.

46 Zob. J. Tischner, Etyka solidarności.

47 Tamże, s. 5-6. Por. wypowiedź tegoż autora w Polskim młynie: „Od długiego już czasu stosunek Polaków do ich własnej Ojczyzny jest trudnym do rozwiązania problemem. Nie jest łatwo być dzisiaj Polakiem. [...] Odpowiedź dąży do zarysowania nowego kształtu polskiego patriotyzmu. [...] Materiałem przemyśleń jest najpierw nasza historia [...]. Innym źródłem jest religia, a w niej myśl Jana Pawła II”. Polski młyn, s. 7. 
w sobie imperatyw wzywający do walki w obronie owych wartości. U Tischnera symbole pełnią raczej przeciwną rolę: odsłaniają i uwyraźniają takie cechy, które ich nosicielom nie przynoszą chluby i z którymi - a nie o które - powinniśmy walczyć. W twórczości Tischnera chciałbym wskazać trzy takie krytyczne symbole: 1. chochoł, 2. kryjówka, 3. młyn.

Pierwszy, podobnie jak u Wyspiańskiego, symbolizuje słomiany zapał; gwałtowną, lecz szybko przemijającą gotowość do brawurowego czynu w obronie jakiejś zagrożonej, fundamentalnej wartości, jak honor czy prawo do samostanowienia; tyle, że pod presją codziennych okoliczności życia z owego zrywu pozostaje tylko gorzkie poczucie bezsilności i żal za głupio zmarnowaną okazją. Tacy jesteśmy - próbuje nam pokazać Tischner, by następnie zmobilizować nas do wytężonej pracy nad przezwyciężeniem ,tragicznego impasu, do którego doprowadza człowieka wybór sarmackiej melancholii jako nastroju dla siebie"48.

Opis, diagnoza i krytyka drugiego symbolu pojawia się w tekście artykułu z 1978 roku Ludzie z kryjówek ${ }^{49}$. Tytułowa „kryjówka” symbolizuje postawę dobrowolnej rezygnacji z ,nadziei [...] zapraszającej do ruchu [...] ku jakiejś przyszłości, w której nadzieja umieściła jego cel' ${ }^{50}$. Wybór tej postawy sprawia, że „,człowiek, zamiast kroczyć swoją drogą, [...] chroni się przed światem i przed innymi”, a „miejsce, w którym stoi, otacza ścianą lęku. Ku wszystkim ludziom zbliżającym się do kryjówki kieruje podejrzenie, że zbliżają się po to, by go okraść i zniszczyć" ${ }^{51}$. Taki styl bycia znamionuje, zdaniem Tischnera, ,upadek [...] o głęboko etycznym znaczeniu”; ,znamiennym rysem ludzi z kryjówek jest to, że sami cierpią i innym przysparzają cierpień" 52 . I znów - opis pełni funkcję nie tylko diagnostyczną (tacy jesteśmy lub możemy się takimi stać), lecz również terapeutyczną, jako że jasne uświadomienie sobie zagrożenia jest już początkiem drogi wyjścia z niebezpieczeństwa. Jednakże - przestrzega Tischner - „rozwiązanie tragedii ludzi z kryjówek nie jest zadaniem łatwym. Trzeba obudzić w człowieku wiele rozmaitych sił, wiele czynników doprowadzić do harmonii” "53. Na szczęście „istnieją dwie podstawowe warunki wyzwolenia człowieka [z kryjówki]: drugi człowiek i otwarcie na prawdę" 54 .

Pozostał do omówienia trzeci symbol - młyn. We wstępie do książki Polski $m \nmid y n$, zawierającej zbiór tekstów pisanych z potrzeby bieżącego komentowania

\footnotetext{
48 J. Tischner, Chochot sarmackiej melancholii, w: tenże, Świat ludzkiej nadziei, s. 27.

49 Tenże, Ludzie z kryjówek, „Znak” 1978, nr 1 (283), s. 57-72; przedruk w: Myślenie wedlug wartości, Kraków 982, s. 415-433.

50 Tenże, Myślenie wedlug wartości, s. 415.

51 Tamże, s. 415-416.

52 Tamże, s. 416.

53 Tamże, s. 429.

54 Tamże, s. 430.
} 
wydarzeń na burzliwej polskiej scenie publicznej lat osiemdziesiątych, autor pisze: „Zastanówmy się chwilę nad metaforą młyna. [...] Rzućmy okiem na zebrane tutaj artykuły i rozważania: one są jakimś skromnym owocem młyna. Nie jest to więc już surowy zapis doświadczeń, robiony w locie, na gorąco. Ale nie jest to jeszcze gotowy chleb na pokarm dla wszystkich. Gdyby to jeszcze raz przemyśleć, jeszcze raz przepisać, gdyby zrobić z tego jakąśs syntezę... ale to już niemożliwe. Artykuły należą do czasu, w którym powstały"55.

Powyższa autocharakterystyka, choć pisana w styczniu 1990 roku, żywo przypomina zanotowaną już z w 1977 roku, krytyczną uwagę o własnym stylu myślenia: „Wiem, że idąc na kolejne spotkanie z człowiekiem, kolejne kazanie, kolejną popularyzację, będę gdzieś w głębi duszy dręczony myślą, że nie robię tego, co robić powinienem. Zawsze muszę kopać o te pół metra dalej, niż - jak mi się wydaje - znajduje się mój skarb. [...] I chyba tak będzie do końca życia. Powiem wtedy: nie zrobiłem tego, co zrobić chciałem, nie zrobiłem tego, co zrobić mogłem, nie zrobiłem nawet tego, co naprawdę trzeba było zrobić" 56 .

W zaprezentowanym kontekście interpretacyjnym młyn funkcjonuje jako symbol jeszcze jednej cechy, typowej nie tylko dla specyficznego temperamentu Tischnera, ale niemalże stereotypowo przypisywanej wszystkim Polakom: wiecznej prowizorki, ciągłego gonienia za wielkim celem, którego realizacja wymagałaby cierpliwości, konsekwencji i systematyczności, a tymczasem nie można sobie na to pozwolić, bo wciąż przynaglają nas do działania coraz nowe, coraz szczytniejsze cele. I po raz kolejny wybrzmiewa w duszy czytelnika ten sam refren: tacy jesteśmy; zatrzymajmy się na chwilę i pomyślmy, jak to zmienić, byśmy bardziej efektywnie mogli oddać się w służbę najważniejszym dla nas wartościom - ot, na przykład dobru ojczyzny.

\section{DWA DRAMATY, DWIE INTERPRETACJE}

Zaznaczone wyżej różnice w pojmowaniu niektórych kluczowych kwestii, dotyczących specyficznego dla naszej narodowej wrażliwości połączenia (jak powiedziałby Tischner) dwóch dramatów - człowieka z Bogiem i człowieka z ojczyzną - wynikają po części z odmiennych punktów wyjścia obu refleksji. Stefan Wyszyński, piastując najważniejsze w Polsce stanowisko kościelne, ani na chwilę nie mógł zapomnieć o ciążących na nim obowiązkach i związanym z nim zakresem odpowiedzialności. Rozwiązując problemy i wątpliwości związane z osobistym przeżywaniem swojego stosunku do wiary i do polskości, równocze-

\footnotetext{
55 Tenże, Polski mtyn, s. 5-6.

56 Tenże, Czym jest filozofia, którą uprawiam, „Znak” 1977 nr 11-12 (281-282), s. s. 1354-1358.
} 
śnie myślał w kategoriach racji stanu i nieustannej troski o sprawy publiczne ${ }^{57}$. Tymczasem styl wiary, charyzmat duszpasterski i stosunek do życia publicznego Józefa Tischnera opierają się na zupełnie innych fundamentach. Był duszpasterzem, człowiekiem głębokiej wiary i Polakiem, ale był też oryginalnie myślącym filozofem. Obszar jego zainteresowań - choć trafniej byłoby powiedzieć: pasji - ulegał stopniowej zmianie. Zanim w owym obszarze pojawiły się na szerszą skalę problemy społeczne (co nastąpiło wraz z początkiem burzliwych lat 80 ., pod ciśnieniem gwałtownych i dramatycznych przemian na polskiej scenie politycznej), Tischner-filozof, a także Tischner-kapłan koncentrował się na problemach pojedynczego człowieka i dramacie ludzkiej egzystencji. Jak napisał w swej mini-autobiografii naukowej, od czasu rozpoczęcia (zaraz po studiach) konkretnej pracy duszpasterskiej, od marzeń o uprawianiu wielkiej, akademickiej filozofii skutecznie odrywały go spotkania z ludźmi, którzy - każdy na swój sposób - przeżywali własne „duchowe biedy”58. Postanowił więc przyjrzeć się owym biedom i ,dobrze radzić" ${ }^{59}$ ich nosicielom, wykorzystując do tego warsztat badawczy filozofa specjalisty w zakresie fenomenologii i hermeneutyki, z czasem rozwijającego coraz bardziej samodzielny styl myślenia.

Na drodze tych poszukiwań dokonał dwóch ważnych odkryć. Pierwsze głosi, że najważniejszym dramatem człowieka jest jego relacja z Bogiem ${ }^{60}$. Drugie - że najboleśniej odczuwaną ludzką biedą jest ta, która wynika z ograniczeń wolności ${ }^{61}$. Odkrył ponadto, w jaki sposób obie kwestie łączą się ze sobą: po pierwsze przez to, że pierwotnym i podstawowym doświadczeniem ograniczenia ludzkiej wolno-

57 Zob. https://dzieje.pl/ksiazki/prymas-wyszynski-ojciec-ojczyzny (7.10.2021).

58 „Tak się jakoś złożyło, że najpierw zacząłem uczyć się filozofii, a dopiero potem naprawdę spotkałem się z człowiekiem. [...] Przyszły rozmowy z ludźmi, spotkania, rozstania; konfesjonał, katecheza, kazanie [...]. Wiem, że idąc na kolejne spotkanie z człowiekiem [...] będę gdzieś w głębi duszy dręczony myślą, że nie robię tego, co robić powinienem. [...] Czy nie lepiej jest uprawiać filozofię [...]?”, J. Tischner, Czym jest filozofia, która uprawiam, w: tegoż, Myślenie wedlug wartości, s. 9-10, 12-13.

59 „Wybrałem, aby być ciasnym i tępym filozofem Sarmatów. Staram się im wymyślać i dobrze im radzić. Na szczęście niezbyt mnie słuchają, więc i wina moja nie będzie zbyt wielka" - pisał z charakterystyczną dla siebie autoironią: tamże, s. 11 .

60 „Pytanie o Boga jest istotnym pytaniem człowieka jako istoty dramatycznej. [...] Wśród rozmaitych opinii i przypuszczeń jedno jest szczególnie godne uwagi: właściwie istnieje tylko jeden dramat - dramat człowieka z Bogiem. Każdy inny dramat i inny wątek dramatyczny jest jedynie fragmentem tego dramatu". Tenże, Filozofia dramatu, s. 22-23.

${ }^{61}$ „Człowiek dąży do wolności. Znaczy to, że nie chce być posiadany. Niewola na tym bowiem polega, że się jest w czyimś posiadaniu. Aby osiągnąć wolność, człowiek musi wybrać inne posiadanie niż to, w którym się znalazł. Musi się wznieść ponad siebie. Ale nigdy tak nie będzie, by posiadał, a sam nie był posiadany. Na tym polega dramat człowieka i jego wolności”. Tenże, Spowiedź rewolucjonisty, Kraków 2016, s. 39. 
ści jest zniewolenie przez grzech ${ }^{62}$, a grzech to jądro dramatu człowieka z Bogiem; po drugie przez to, że ludzie najbardziej skłonni do ograniczania wolności innych, do przemocy i zniewolenia to ci, co nie mają Boga w sercu ${ }^{63}$.

Te odkrycia generują nieco inną optykę widzenia problemów, które na własny sposób dostrzegał i rozwiązywał również Stefan Wyszyński. Przyjrzyjmy się dla przykładu kwestii grzechu. Dla prymasa powinność walki z własną skłonnością do grzechu wiąże się bezpośrednio z kondycją duchową i siłą moralną narodu. Im bardziej jesteśmy skłonni do pobłażania własnym i cudzym grzechom - zwłaszcza tym, które składają się na katalog „polskich grzechów głównych” ${ }^{64}$ - tym większa słabość całej wspólnoty i jej podatność na perfidną demoralizację ze strony sił wrogich zarówno wierze katolickiej, jak najżywotniejszym interesom narodu. Dlatego w pracy duszpasterskiej Wyszyńskiego wezwania do nawrócenia grzeszników łączą się ściśle z troską o wzrastanie w siłę polskiego narodu.

Dla Tischnera z kolei, grzech to przede wszystkim osobisty dramat człowieka, który - powołując się na sobie wiadome racje - buntuje się przeciwko Bogu i Jego przykazaniom. Jeśli tak, to pomoc grzesznikowi w jego duchowej biedzie powinna polegać przede wszystkim na poprowadzeniu go ku wewnętrznemu przeżyciu doświadczenia wyzwolenia poprzez uświadomienie, że prawdziwa wolność to nie wolność od przykazań, lecz wolność od grzechu. Dlatego autor Nieszczęsnego daru wolności wielokrotnie powtarzał, że „wolność to sposób istnienia dobra”, a nie - możliwość czynienia wszystkiego, co się chce.

Te dwie optyki postrzegania grzechu - poprzez ideę nawrócenia jako powinności patriotycznej i jako drogi do prawdziwej wolności - znakomicie się uzupełniają. Mają więc charakter komplementarny, a nie antagonistyczny. Podobnie będzie z innymi wątkami, które zostaną poruszone dalej. Tu natomiast warto jeszcze zwrócić uwagę, że każda z dwóch strategii przezwyciężania skłonności do grzechu pozwala sięgać po inne instrumenty walki duchowej. W optyce Wyszyńskiego tym, co pomaga uporać się z własną grzesznością jest świadomość, że nie jestem osamotniony, bo wraz ze mną na drogę nawrócenia wchodzą miliony moich bliźnich, a do naszej dyspozycji oddaje się cały Kościół ze swą posługą duszpasterską i sakramentalną. W ujęciu Tischnerowskim natomiast, decydującą rolę

62 „Są rozmaite odmiany zniewolenia. Chodzi nie tylko o to, że człowiek jest wszechstronnie zależny - dziecko od rodziców, dorosły od pogody, zdrowia, przełożonego - ale o to, że wszyscy jako ludzie są zniewoleni przez grzech. Grzech to podstawowe zło, przyklejone do natury ludzkiej. Grzech zniewala bardziej niż wszystko inne”. Tenże, Nieszczęsny dar wolności, Kraków 1993, s. 11.

63 Zob. tenże, Spowiedź rewolucjonisty, s. 42-47.

${ }^{64}$ Siedem kolejnych wezwań, zawartych w tekście Jasnogórskich Ślubów Narodu Polskiego, można interpretować również jako apel do wszystkich Polaków, by uczynili generalny rachunek sumienia ze szczególnym uwzględnieniem tych grzechów i zaniedbań, na które wskazuje tekst. Zob. Tekst Jasnogórskich Ślubów Narodu Polskiego, dostępny online http://www.wyszynski.psur. pl/sluby.php (1.10.2021). 
odgrywa możliwość wejścia z powrotem w relację miłości i zawierzenia Bogu dzięki pośrednictwu spotkanego na swej drodze kapłana, który jako spowiednik lub przewodnik duchowy otwiera przestrzeń spotkania z Transcendencją. Dzięki takiemu poszerzeniu pola możliwości działania wzrasta skuteczność duszpasterskiej posługi Kościoła. To niewątpliwy zysk, płynący z opisanego wyżej ,ukrytego dialogu" między Wyszyńskim i Tischnerem.

\section{PODSUMOWANIE}

Celem dokonanego tu przeglądu problemów i motywów, związanych u obu wyjątkowych polskich kapłanów z ich autentyczną troską i głębokim poczuciem odpowiedzialności za losy ojczyzny, było ukazanie, że te dwa projekty ,pracy nad Polską", jak można by je nazwać (parafrazując wypowiedź Tischnera o potrzebie podjęcia ,pracy nad polską pracą" ${ }^{65}$ ) znakomicie się uzupełniają. Nie ma jednego modelu Polaka-patrioty, do którego wszyscy musielibyśmy się dopasować, i nie ma jednego, standardowego wzorca Polaka-katolika, obowiązującego dla wszystkich ochrzczonych mieszkańców naszej ojczyzny. Różne są typy wrażliwości, różne sposoby przeżywania indywidualnego przywiązania do tych wartości, których źródłem promieniowania są Bóg i ojczyzna.

Polska i Kościół to dwie wielkie wspólnoty, skupiające miliony ludzi. Chcielibyśmy, aby obie były przyjaźnie otwarte dla każdego, komu bliskie są ideały polskości i katolicyzmu, niezależnie od tego, w jaki dokładnie sposób je rozumie i przeżywa. W szczególności tożsamość Kościoła katolickiego opiera się na zasadzie ,jedności w różnorodności” ${ }^{66}$. Dotyczy to zarówno Kościoła powszechnego, w skali całego świata, jak też poszczególnych Kościołów regionalnych, również w naszym kraju. Tym, co zespala w jedno wszystkie drogi Kościoła, jest człowiek ${ }^{67}$, gdyż „Kościół powstaje z odpowiedzi dawanej przez ludzi Słowu Bożemu [i] ta odpowiedź łączy ich i zespala we wspólnotę"68. Jak pisał Karol Wojtyła, „wspólnota wyrastająca z tej odpowiedzi, z dialogu z Bogiem, określa jakby pionowy wymiar Kościoła. Równocześnie zaś wspólnota jest otwarta ku wszystkim ludziom.

${ }^{65}$ „Chcę tę polską pracę zrozumieć, określić ją, uchwycić jej istotę, aby na tej drodze podjąć dzieło - pierwsze dzieło w historii Polski - pracy nad pracą" - mówił Tischner podczas I Zjazdu NSZZ „Solidarność” w Gdańsku. Zob. J. Tischner, Niepodległość pracy, w: tenże, Polska jest Ojczyzna, Paris 1985, s. 27.

66 Zob. A. P. Perzyński, Jedność przez różnorodność Kościoła, „Studia Gnesnensia” 2015, T. XXIX, s. 143-155; S. Pawłowski, Teologia jedności Kościoła. Zarys problematyki, „Studia Nauk Teologicznych" 2015, T. 10, s. 185-197.

67 Zob. K. Wojtyła (Jan Paweł II), Człowiek droga Kościoła, red. K. Czajkowska, Rzym 1992.

68 A. Zuberbier, „Człowiek drogą Kościoła”: o eklezjologii Jana Pawła II, „Studia Theologica Varsaviensia" 1990, 28/1, s. 158; por. K. Wojtyła, U podstaw odnowy, Kraków 1972, s. 30. 
Wiara zespolona z dialogiem kształtuje wymiar poziomy Kościoła"69. Dlatego warto potraktować przypomniane wyżej wypowiedzi Stefana Wyszyńskiego i Józefa Tischnera jako dwa ważne głosy w dialogu, prowadzonym w imię wiary i miłości ojczyzny w „poziomym wymiarze”, łączącym troskę o każdy z tych obszarów i pokazującym konkretne modele postaw, z którymi możemy się utożsamić lub zaczerpnąć z nich inspirację do dalszych przemyśleń.

\section{Bibliografia}

Bonowicz W., Tischner, Kraków 2001.

Czaczkowska E. K., Kardynat Wyszyński, Warszawa 2009.

Czaczkowska E. K., Zwycięski plan - jedność i katolicyzm masowy, „Rzeczpospolita" 27.05.2011, w: https://www.rp.pl/artykul/664230-Zwycieski-plan--jednosc-i---katolicyzm-masowy.html (1.10.2021).

Eisler J., Czterdzieści pięć lat, które wstrzasnęty Polska. Historia polityczna PRL, Warszawa 2018.

Fiut A., Ukryty dialog, „Teksty Drugie”, nr 3, 2000, s. 148-156.

Grzybowski R. (2018), Idea wychowania nowego czlowieka (homo sovieticus) i jej odzwierciedlenie w założeniach programowych Wszechzwiąkowej Organizacji Pionierskiej, „Polska Myśl Pedagogiczna” nr 4, 2018, s. 297-322.

Kijas Z. J., Wyszyński. Narodziny nowego człowieka, Warszawa 2021.

Kruszyńska A., Prymas Wyszyński. Ojciec Ojczyzny, w: https://dzieje.pl/ksiazki/ prymas-wyszynski-ojciec-ojczyzny (1.10.2021).

M. G.-K., Internowanie Prymasa Wyszyńskiego, w: https://muzhp.pl/pl/e/1661/ internowanie-prymasa-wyszynskiego $(1.10 .2021)$.

Marek Ł., Kompromis w pewnych granicach. Porozumienie państwo-Kościót z 1950 roku, w: Instytut Pamięci Narodowej, w: https://krakow.ipn.gov.pl/pl4/ edukacja/przystanek-historia/95442,Kompromis-w-pewnych-granicachPorozumienie-panstwo-Kosciol-z-1950-roku.html (1.10.2021).

Micewski A., Kardynat Wyszyński prymas i mąż stanu, Paryż 1982.

Michnik A., Tischner J., Żakowski J., Między panem a plebanem, Kraków 1985.

Mickiewicz A., Dziady. Część III, w: Dzieła. Tom III. Utwory dramatyczne, Warszawa 1955, s. 127-305.

Mickiewicz A., Pan Tadeusz, Księga czwarta. Dyplomatyka i łowy, w: http:// www.lektury.waw.pl/77/78/pan-tadeusz (1.10.2021).

Norwid C. K., Pisma polityczne i społeczne, Warszawa 1983.

${ }_{69}$ Tamże. 
Okońska M., Wszystko postawił na Maryję, Warszawa 2017.

Pawłowski S., Teologia jedności Kościoła. Zarys problematyki, „Studia Nauk Teologicznych", T. 10, 2015, s. 185-197.

Perzyński A. P., Jedność przez różnorodność Kościoła, „Studia Gnesnensia”, T. XXIX, 2015, s. 143-155.

Pietrzak J., Przywileje i godności Prymasów Polski, „Studia Prymasowskie” nr 5, 2011, s. 57-98.

Przyczyna W., Siwek G., Język w Kościele, w: Polszczyzna 2000. Orędzie o stanie języka na przełomie tysiącleci, red. W. Pisarek, Kraków 1999, s. 130-148.

Rastawicka A., Ten zwycięża, kto miluje. Życie i nauczanie prymasa Stefana Wyszyńskiego, Warszawa 2019.

Ryszka C., Prymas Wyszyński. Ojciec Ojczyzny, Kraków 2020.

Szarek J., Duszpasterz i mąż stanu. Czterdziesta rocznica śmierci kardynata Stefana Wyszyńskiego, „Bezpłatny dodatek do “Gościa Niedzielnego”, 23 maja, 2021, s. 2.

Ślipko T. (1967), Pojęcie człowieka w świetle wspótczesnej antropologii marksistowskiej w Polsce, „Zeszyty Naukowe KUL”, T. 10, z. 2, 1967, s. 3-16.

Tekst Jasnogórskich Ślubów Narodu Polskiego, w: http://www.wyszynski.psur. pl/sluby.php (1.10.2021).

Tischner J., Czym jest filozofia, która uprawiam, „Znak” nr 11-12 (281-282), 1977, s. $1354-1358$.

Tischner J., Etyka solidarności, Kraków 1981.

Tischner J., Filozofia dramatu, Kraków 1998.

Tischner J., Ludzie z kryjówek, „Znak” nr 1 (283), 1978, s. 57-72

Tischner J., Myślenie wedtug wartości, Kraków: Znak .

Tischner J., Na drogach krzyżowych historii, Kraków 1982.

Tischner J., Nieszczęsny dar wolności, Kraków 1993.

Tischner J., Ojczyzna - o co tutaj chodzi?, w: J. Tischner, Nadzieja mimo wszystko, Wybór i oprac. W. Bonowicz, Kraków 2020.

Tischner J., Polska jest Ojczyzna, Paris 1985.

Tischner J., Polski kształt dialogu, Paris 1981.

Tischner J., Polski mlyn, Kraków 1991.

Tischner J., Spowiedź rewolucjonisty, Kraków 2016.

Tischner J., Świat ludzkiej nadziei, Kraków 1975.

Tischner J., W kręgu filozofii pracy, Kraków 1983.

Wierzbicki A., Piastowski Wyszyński, jagielloński Wojtyła. Dwie chrześcijańskie interpretacje polskości, „Więź” 2017, nr 5, w: https://wiez.p1/2017/05/05/piastowski-wyszynski-jagiellonski-wojtyla-dwie-chrzescijanskie-interpretacje-polskosci/ (1.10.2021).

Wojtyła K., Człowiek droga Kościoła, red. K. Czajkowska, Rzym 1992.

Wojtyła K., U podstaw odnowy, Kraków 1972. 
Wyszyński S., 2. Kazanie Świętojańskie Prymasa Polski, Poznań-Warszawa 1980.

Wyszyński S., Kocham Ojczyznę więcej niż własne serce. Wybór tekstów, red. B. Dembińska, Częstochowa 2020.

Zuberbier A., Człowiek droga Kościoła: o eklezjologii Jana Pawła II, „Studia Theologica Varsaviensia", T. 28, 1990, z. 1, s. 157-162 